$$
\text { サッカー選手の体力評価 }
$$

\title{
Evaluation of the Physical Strength of Soccer Players
}

宮森 隆行 ${ }^{1)}$ 吉村 雅文 $^{1)}$ 青葉 幸洋1)

TAKAYUKI MIYAMORI ${ }^{1)}$, MASAFUMI YOSHIMURA ${ }^{1)}$, YUKIHIRO AOBA ${ }^{1)}$

1) Department of Health and Sports Science, Juntendo University: 1-1 Hiragagakuendai, Inba-mura, Inba-gun, Chiba 270-1695, Japan. TEL +81 476-98-1001 FAX +81 476-98-1028

Rigakuryoho Kagaku 23(5): 685-690, 2008. Submitted Mar. 17, 2008. Accepted May 1, 2008.

ABSTRACT: In this study, we evaluated the physical strength of soccer players from the following 4 aspects: physical strength factors required for soccer players, measurement of the physical strength and evaluation, application of results, and training problems to be considered in the future. Results: Understanding the characteristics of soccer is important in the evaluation of the physical strength of soccer players. It was also confirmed that individual and group evaluation of physical strength is important to increase the efficiency of physical training. The quantitative evaluation of the relationship between physical strength factors, training, and sports performance will be a step toward making effective use of scores of physical strength for soccer players.

Key words: physical strength, sports characteristics, training

要旨: 本稿では, サッカー選手の体力を,「サッカー選手に必要とされる体力要素」,「体力測定と評価」,「結果の 活用」, さらに,「今後取り組むべきトレーニング課題」の4点から検討した。その結果, サッカー選手の体力を評 価するためには，競技特性を理解した中での体力評価を実施することが必要であり，これらを考慮に入れた個別 化・グルーピング化した体力評価は, サッカー選手の体力トレーニングの効率化を図る上での重要な評価であるこ とが確認された。今後のサッカー選手の体力評価は，「体力的側面」・「トレーニング」・「競技パフォーマンス」の3 要因の関連性を定量的に解明していくことが必要であり, これらの評価を数值化して現場に還元していくことこ そ, 科学的トレーニングの一つのステップであると考える。

キーワード：体力，競技特性，トレーニング

1) 順天堂大学 スポーツ健康科学部：千葉県印旛郡印旛村平賀学園台1-1 （テ270-1695）TEL 0476-98-1001 FAX 0476-98-1028 受付日 2008年3月17日＼cjkstart受理日２008年5月1日 


\section{I.はじめに}

チームが目指すサッカーを確立していくためには, 選手が，(1)戦術の理解，(2)相手に走り負けないスピー ドとスタミナ，(3)ボールをキープしコントロールする 高いスキル, を備えてプレーしなければチームとして 戦えない1)とされている。また近年では, 戦術における 守備面でのプレッシングという方法の導入により, 相 手の技術を発揮するために必要な時間とスペースを限 定することによってボールを奪い, 素早い攻守の切り 替えから得点を奪うプレースタイルが多く見受けられ る。さらに, 競技レベルと比例して試合中のプレッシ ングは激しくなり，時間とスペースが限られた中でい かにして攻撃を活性化するかが思考錯誤され, サッカー 選手に求められる体力水準も非常に高くなってきてい る2)。これらの状況を踏まえ, サッカーの競技能力を評 価していく上では, 技術・戦術・体力等の要因が複合 的に絡み合ってくる。中でも体力的要因は数值化する ことが可能であるため, 競技能力を客観的に評価する のに適した要因であると言える。

そこで本稿では, サッカーの競技特性を紹介しなが ら,「サッカー選手に必要とされる体力要素」,「体力測 定と評価」,「結果の活用」, さらに, 「今後取り組む心゙ きトレーニングの課題」の 4 点について検討した。

\section{II. サッカー選手に必要とされる体力要素}

1. 試合中に要求される動き

サッカー選手に必要な体力要素を検討する場合, 実

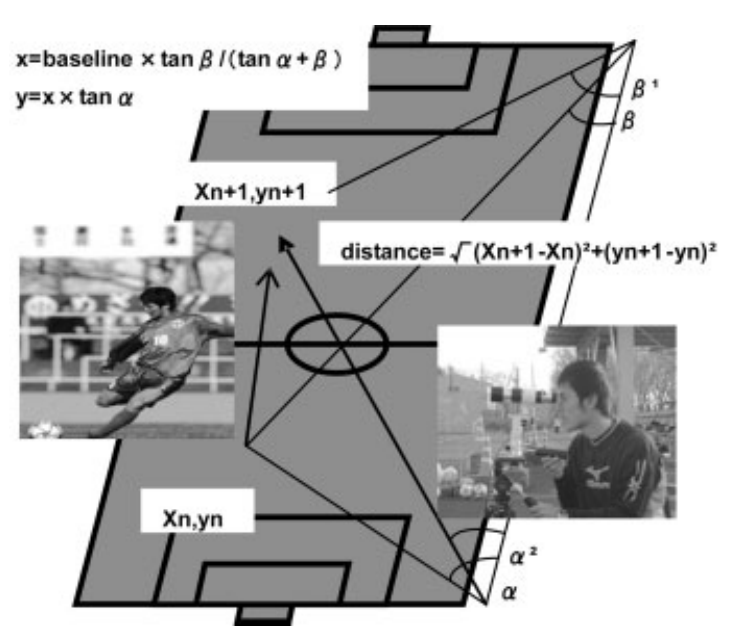

図1 実際の試合中の移動距離・移動スピードの測定方法

際の試合中に要求される動きを明確にしておく必要が ある。動きの特性においては, 図1, 眓2のようにトップ レベルの大学サッカー選手を対象に, 高速移動解析シス テム（DKH 社製）を利用して，試合中の移動距離と移 動スピードを明らかにしたところ, 移動距離は9.7〜 13.4 $\mathrm{km}$ であり, 選手は2 3 $\mathrm{m} / \mathrm{sec}$ で移動しながら時折 $7 \mathrm{~m} / \mathrm{sec}$ 以上の早いスピードでフィールドを移動していた3)。ま た，宮城らは，Jリーグの選手を対象に試合中の移動距 離・移動スピードを検証したところ, 総移動距離は 10.3 $\sim 12.5 \mathrm{~km}$ であり, 時折 $8 \mathrm{~m} / \mathrm{sec}$ 以上の早いスピードでの 動きを繰り返しており,特にレ心゙ルの高い選手になるほ ど, 相手選手の一瞬の隙を突くような緩急をつけた動き を繰り返し行っていた 4 ,5) と報告している。

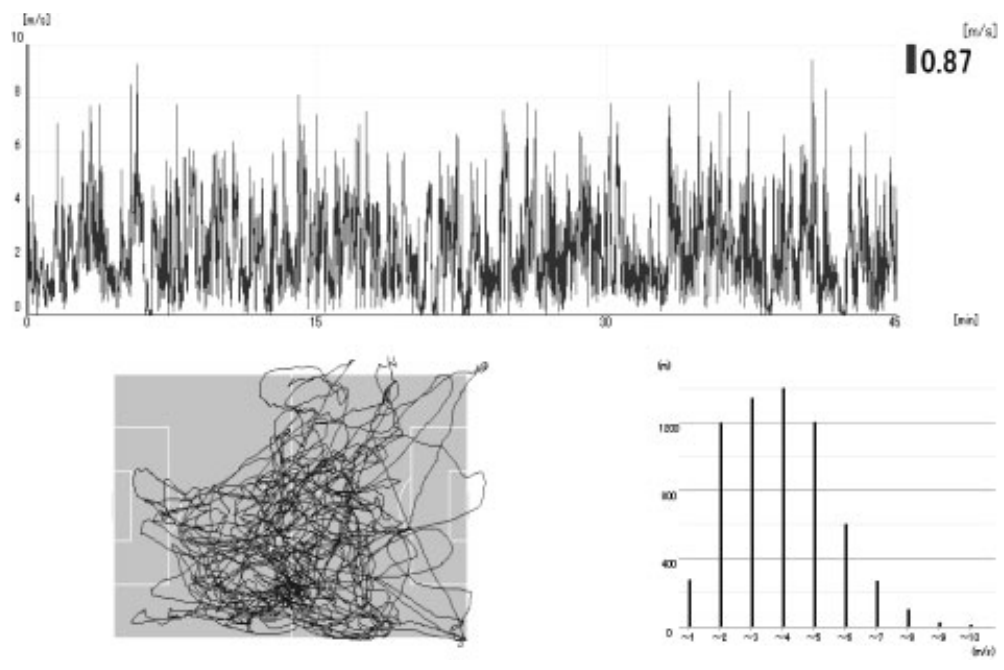

図2 ディスプレイ表示される移動軌跡・移動スピードの変化 
さらに，プロサッカー選手の試合中の Activity Profile を調べた一連の研究では, サッカーのパフォーマンス には, トータルの移動距離よりも, その中で行われる スプリントなどの無酸素性の高強度運動が重要である ことが明らかにされている6)。現在のプロ選手は, 1980 年から 90 年代初頭と比較して, トータルの移動距離に 変化はないものの, $30 \mathrm{~km} / \mathrm{h}(8.3 \mathrm{~m} / \mathrm{sec})$ のスプリント 回数は $37 \%$ 増えているとの報告もある7)。このように サッカー選手の実際の試合中の動きの特徵としては, 長距離を移動しながら, トップレベルの選手ほどダッ シュ等の高強度運動を頻回に要求されていることが明 らかにされている。

\section{2. 生理学的特徵}

サッカーの試合中における平均的な生理学的強度は, 最大酸素摂取量 $\left(\dot{\mathrm{V}} \mathrm{O}_{2} \mathrm{max}\right) 70 \sim 80 \%$, 心拍数 170 拍前 後, 血中乳酸濃度 $5 \mathrm{mmol} / 1$ 前後とされている ${ }^{6,8)}$ 。90分間 の試合での移動距離が $10 \mathrm{~km}$ と仮定すると, 走行速度は 平均で $111 \mathrm{~m} / \mathrm{min}(1.85 \mathrm{~m} / \mathrm{sec})$ となり，これは歩くこと も可能な速度であり, 持続性持久力での $\mathrm{V}_{2} \max$ は $50 \%$ にも満たないと言われている9)。しかし，実際には，心 拍数から推測した場合も, 酸素摂取量を直接測定した 場合も，1試合あたりの $\dot{\mathrm{VO}}_{2} \max$ は70〜80\%と考えられ ている ${ }^{6,8)}$ 。従って, このような結果から, サッカー選 手の試合中の総移動距離における評価は, サッカー選 手のパフォーマンスを直接的に反映させる指標でない と言える。つまり, クイックネス, タイミング, 正確 性, 多様性などの戦術的理解とともに, 技術的な要素 を含めたアジリティードリル，スピード，ドリブル， キック，ジャンプ等の瞬発的な高強度運動を瞬時の判 断で最適に発揮することができるかが重要となってく る1)。しかも，1試合あたりにいかに長時間にわたり， これらの瞬発的な高強度運動を頻回に繰り返すことが できるかが，チームパフォーマンスを評価するのに重 要な指標となっており, 血中乳酸濃度と相関関係があ るとする報告もある10)。さらに，これらの結果を裏付 けるものとして, 我々は, トップレベルの大学選手の 試合中の総移動距離とそれに占める無酸素性および有 酸素性エネルギー機構の動員比率をポジション別で比 較した。その結果, 総移動距離に占める無酸素性スピー ドでの移動の割合は, 各ポジション別の平均が $24.8 \%$ であり ${ }^{3)}$, 他の大学サッカー選手の平均 $10.3 \%{ }^{11)}$ と比較 すると無酸素性スピードでの移動の割合が多いことが 確認された。このように, サッカーの試合においては, トップレベルの選手ほど長い距離を移動するための有
気的能力と, ダッシュやターン等の高強度運動である 無気的能力, さらにこれらの高強度運動を頻回に繰り 返すための間欠的能力が非常に重要な体力要素である と言える。

\section{III. 体力測定と評価}

サッカー選手の体力を効果的に向上させていくには, 先ず, 各選手の体力要素の水準を正確に評価すること が必要である12)。しかし，その評価方法は実験室的測 定からフィールドテストに至るまで様々であり, 活用 方法はクラブや指導者の目的や考え方によって異なっ ている ${ }^{13)}$ 。また, 実験室レベルでの高価な機器類や分 析ソフトを必要とするような体力測定を実施すること は, 選手の負担と得られる情報価值, あるいは検者側 の作業量とのバランスにおいて, 選手, 指導者として も測定を敬遠しがちである。これらの現状を踏まえ, 今後は, 実験室レベルの測定結果を現場に落としこみ, より安価かつ簡易的な方法で実施できるフィールドテ ストを活用していくことが望まれる。

そこで，本稿においては，サッカー選手のパフォー マンス向上を目的とした間欠的能力テスト (Intermittent test）について紹介する。このテストはBangsbo ${ }^{15)} の$ 評価 法に独自のアレンジを加えたものであり, サッカーの 試合中に要求されるアジリティードリルやジャンプ等 の動きを取り入れている。

図 3 に示すこのテストは, 関東大学サッカー 1 部リー グ選手16名を対象として実施したものであり, 方法は,

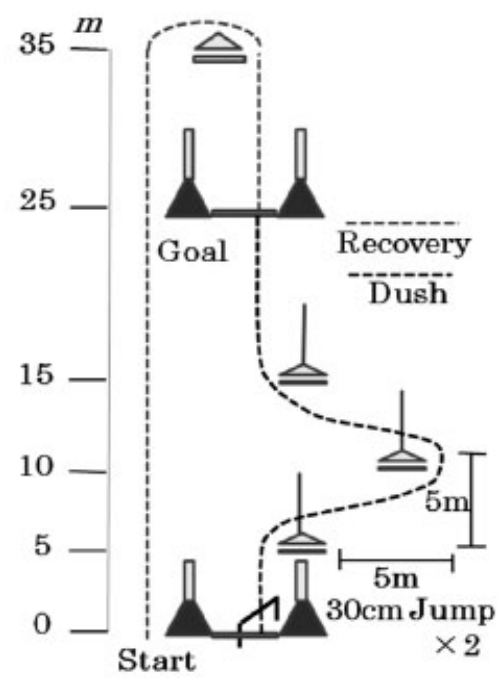

図3 Intermittent test 

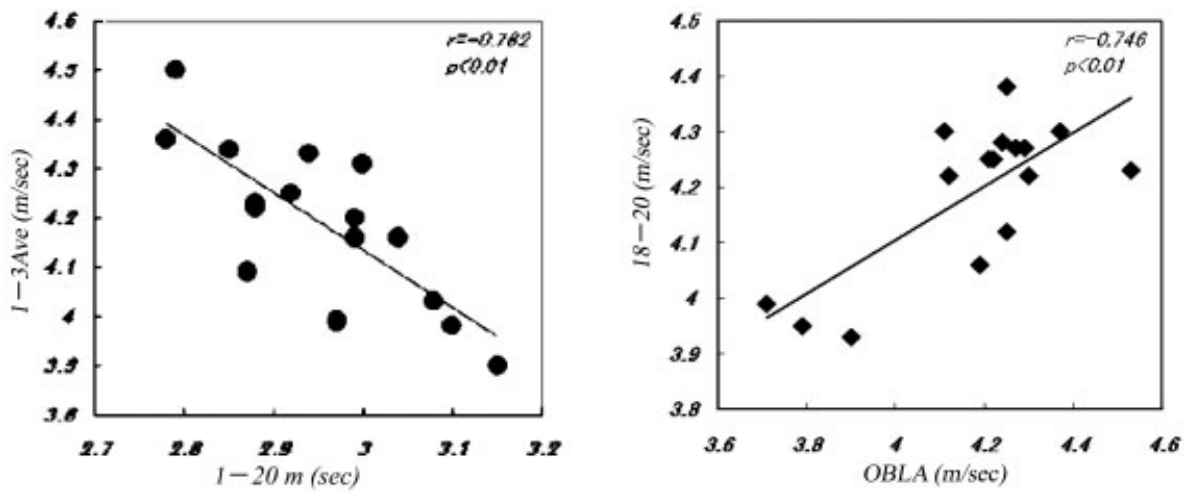

図4 Intermittent testにおける無気的能力と有機的能力の妥当性

スタート時に $30 \mathrm{~cm}$ ジャンプを 2 回実施, $5 \mathrm{~m}$ 先からのス ラロームをクリヤしながら， $25 \mathrm{~m}$ 先のゴールを目指す ものであり, スタートからゴールまでのタイムをパー ソナルタイマー（アクティー社製）を利用して記録し た。ゴール後は，10 $\mathrm{m}$ 先のマーカーでターンをし，リ カバリーをしながらゴールまで戻り，この一連の動き をスタートから 30 秒毎に全20回全力で実施していくテ ストである。そのため, 必然的に前半のスタートから ゴールまでのタイムと, 後半のスタートからゴールま でのタイムに差が出てくる設定となっている。

このテストの結果, 前半の1-3本の平均タイムと $20 \mathrm{~m}$ スピードテストとの比較においては, 四4のように強い 相関が認められた。また, 後半の18-20本の平均タイム と持久性能力を示すOBLA（血中乳酸濃度が $4 \mathrm{mmol} / 1$ 時 の走速度）との比較においても強い相関が認められた。 従って，この間久性能力テストにおいては，前半の1-3 本目は高強度運動である無気的能力を評価し, 後半の 18-20本目は持久的運動である有気的能力を評価するこ とに適していることが確認された。つまり，このテス 卜を実施することにより, サッカー選手に要求される ダッシュ, ターン等の無気的能力と, 筋の酸化能力を 高めることにより持続的な運動を行うための有気的能 力を同時に評価することが可能となる。

また，このテストを坂井ら ${ }^{14)}$ の方法を参考に，図5の ような評価法を利用することにより，リカバリーによ る低強度運動を挟みながら, 高強度運動を頻回に繰り 返す能力，すなわち間欠性能力を構造的に評価するこ とが可能となる。この評価法は, 間欠性能力テストに おける 1 セットから 3 セットまでの平均速度（以下，13Ave）を無気的能力の指標，18から20セットまでの平 均速度 (以下, 18-20Ave) を有気的能力の指標とし, 被

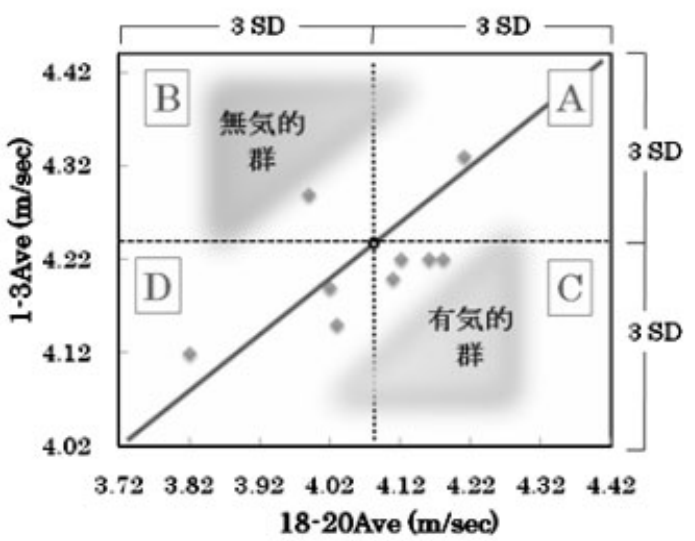

図5 1-3Aveと18-20Aveの関係から判定したグルーピング

験者全体の1-3Ave と 18-20Ave の平均值を通り，1-3Ave の標準偏差（SD）を18-20AveのSDで除した值（1-3Ave のSD／18-20AveのSD）を傾きとする直線をタイプ分け の基準線にしている。

そして，基準線よりも上方に位置する者を，被験者 の中で相対的に無気的能力に優れる無気型群，下方に 位置する者を相対的に有気型群として分類する。更に 図5のA-Dには，被験者全体の1-3Ave と 18-20Aveの平均 值を中心として, 無気的能力と有気的能力の優劣から 被験者を 4 象限にタイプ分けするための基準線も併せ て示している。すなわち， $\mathrm{A}$ 象限は無気的能力と有気 的能力の双方に優れるタイプ， $\mathrm{B}$ 象限は無気的能力に 優れるタイプ, C象限は有気的能力に優れるタイプ, D 象限はいずれのタイプにも劣るタイプに分類すること ができる14)。 


\section{IV. 結果の活用方法}

ここでは，上述したサッカー選手の競技特性を考慮 に入れた間欠的能力評価において, 無気的群と有気的 群の 2 群間の優劣からみた場合と, 4 象限の 4 タイプに 分類した場合とを構造的に解明しながらトレーニング 課題を考えていきたい。まず，無気的群と有気的群の $2 つ に$ 分類した場合, 個人内でのバランスという観点か らみると, 間欠的能力を向上させるためには, 第一に 相対的に有気的群になることが必要となる15)。なぜな ら, サッカー選手に必要とされる間欠性能力を向上さ せるための体力をエネルギー供給機構から考えていく と, 試合中に無気的な動きを不規則に繰り返すことに より, 乳酸が蓄積し, 筋中 $\mathrm{Ph}$ も低下し, やがて筋肉の 収縮に悪影響を及ぼすことになる。そのため, トレー ニングによって有気的能力を高めることで筋の酸化能 力を高めていくことが必要である。また, 有気的能力 の向上は, 非乳酸性や乳酸性供給機構からエネルギー 供給の動員割合を抑えることにもつながってくる。い わば，有酸素性能力はサッカー選手の土台として高め ておかなければならない体力要素でもある16)。そのた め, 個別に測定した選手の無気的能力, 有気的能力の レベルとバランスを考慮に入れた上で, 各選手がそれ ぞれ個人内で相対的に有気的群になるように, 各選手 ごとにトレーニング課題を設定していくことが必要で ある ${ }^{15) 。}$

次に, エネルギー産生能力から4タイプに分類した場 合では, 相対的に無気的能力に優れるBタイプは, 先に 述べたように回復能力を高めるための有気的能力を高 めることが必要であり, 高強度運動を頻回に繰り返し ても, 筋収縮力が低下しないようなトレーニング課題 を設定していく必要がある。これに対して, Cタイプ は, 土台となる有気的能力が相対的に優れているため, サッカーの試合におけるダッシュやターン, ジャンプ といった無酸素的な動きの瞬発力やパワーを高めて, 間欠的能力発揮における全体的なバランスを向上させ ていくためのトレーニング課題を設定することが必要 である。最後に, 無気的能力・有気的能力のいずれの 能力にも優れる A タイプに属する選手であるが, この タイプは，一見トレーニング課題がないように思われ る。しかし, この評価は, 対象者全体における対象者 間評価であり, 対象者間の間欠的能力を相対的に分類 したものであることを考慮しなければならない。つま り，今回の測定で A タイプに分類されたとしても，よ り競技レベルの高い対象者間における評価においては,
A タイプに属するとは限らない。そのため, さらに無 気的能力と有気的能力のバランスを高めるためのトレー ニング課題を設定していく必要がある。

\section{V. 今後取り組むべきトレーニングの課題}

1. 体力トレーニングの効率化

サッカーに求められる体力的水準が高くなる一方で, 技術・戦術の進化も著しい。そのため, 日々のトレー ニングにおいてボールを扱う技術・戦術練習を評価せ ず，抽象的に体力トレーニングばかりに時間を割いて いれば高いパフォーマンスが得られないことは言うま でもない。また, サッカー競技に必要な体力の向上を 図るトレーニングを実施する場合，ボールを使用した

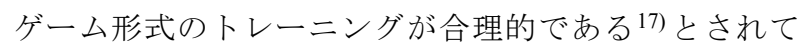
いる。その理由としては, (1)技術や戦術のトレーニン グに効果がある, (2)サッカーに特有な筋のトレーニン グが可能である，(3)選手の動機づけが高くなる，など があげられている17)。つまり, サッカー選手の体力ト レーニングを実施するうえでは, 体力トレーニングが サッカーのパフォーマンスを向上させるのではなく, 技術・戦術トレーニングの目的, 運動強度と時間, 休 悡時間等をしっかりと把握した上での補足的な手段と して体力トレーニングを実施していくことが必要であ る。そのため, 実施する体力トレーニングには効率性 が求められ, 短時間で最適なトレーニング効果を期待 されるようになってきている。

しかし, 実際多くのサッカーのトレーニング現場で は, 選手の体力的な初期評価を実施せずトレーニング を実施しているため, 選手個々人において最適なトレー ニング効果が得られているかについて判断できていな いのが実情である。また, 体力的な初期評価を蓄積し ていても，実施するトレーニングが各選手の体力的な ストロングポイントとウィークポイントを明確に捉え て処方されたものではなく, 全体トレーニングとして 抽象的に処方されたものであれば，実施されたトレー ニングによって急速な成長を遂げる選手がいる一方で, 同じトレーニングなのに全く反応をしない選手もおり, これらの現状は効率性を追求した体力トレーニングと は言いがたい。

2. 体力トレーニングの個別化

「個別性」はトレーニングの原則でもあるが，サッ カーにおいては，集団競技という特性上，みな一律に 同様のトレーニングをすることが当然とされてきたた 
め, それを本当の意味で実践するのは必ずしも容易で はなかった ${ }^{18)}$ 。そのため, 今後は選手の体力的な個別 評価を実施し, 個々のストロングポイント, ウィーク ポイントを明確に捉えた個別化・グルーピング化され た体力トレーニングを実施していく必要がある。また, サッカーにおける体力的な準備においては，一般的な 体力を全面的に向上させることにとどまらず, サッカー 競技に特有の専門的な体力，特に間欠的能力を向上さ せることが競技力向上には重要な鍵となってくる。従っ て, 間欠的運動能力を目標レベルまで高めていく為に は, 個々の体力要素を個別に評価していくことに加え て, それらの要素を間欠的能力を構成する要素として 構造的に捉えていく視点が必要となってくる。

\section{VI. おわりに}

サッカーの体力に関する研究においては, 従来, 体 力測定 (初期評価) 一トレーニング一体力測定 (トレー ニング内容の検討および修正）一トレーニング一体力 測定（トレーニング効果の判定）というものが，いわ ゆる「科学的なトレーニング」とされてきた。しかし， 体力的側面からサッカー競技を診るのではなく, サッ カーという競技種目の特性から体力的側面を診ていく ことが重要であり, 体力面の準備は, チームが目指す 戦術を忠実に消化していくための一要素に過ぎない。 そのため,「体力的側面」,「トレーニング」，「競技パ フォーマンス」の3 要因の関連性を定量的に解明してい くことこそ, 数值化したものを現場に還元していく科 学的トレーニングの一つのステップであると考える。 そして，そこにはサッカーの競技特性を理解し，その チームの進むべきべクトルを揃えながら, 選手や監督 のみならず, コーチ, フィジカルコーチ, 医師, 理学 療法士，アスレティックトレーナー，管理栄養士， ら の協力のもとでそれぞれの専門分野における科学的な 知識を共有し, 選手およびチームパフォーマンスの向 上に向けて, より専門性を発展させた取り組みを実行

していくことが重要である。

\section{引用文献}

1) 宮村 司: サッカー選手の体力特性. 理学療法. 2005, 22(1): 305-313.

2) 滝井敏郎 : ワールドサッカーの戦術. 初版ベースボールマガ ジン社, 1995, pp2-27.

3) 宮森隆行, 吉村雅史, 綾部誠也・他 : 大学サッカー選手のポ ジション別体力特性に関する研究. 理学療法科学 (印刷中).

4) 宮城 修, 山下則之, 大橋次郎・他：J リーグ選手の体力之 試合中の動きについて．バイオメカニクス研究，1999， 3: 125-131.

5) 宮城 修, 大橋二郎, 瀧 剛志 : サッカーの移動スピードと 距離からみたポジション間の比較. 日本体育学会第55回大会 号, 2004, 528.

6) Bangsbo J: The physiology of soccer with special reference to intense intermittent exercise. Acta Physiol Scand, 1994, 151(Suppl 619): 1-153.

7) Mohr M, Krustrup P, Bangsbo J: Match performance of high-standard soccer players with special reference to development of fatigue. J Sports Sci, 2003, 21: 519-528.

8) Bangsbo J, Mizuno M: Morphological and metabolic alterations in soccer players with detraining and retraining and their relation to performance. Science and Football, E\&FN Spon, London, 1988, pp114-124.

9) 星川佳広 : サッカーの生理学的特性と一流選手の体力. 体育 の科学, 2002, 52(5): 355-366.

10) Bangsbo J: Activity profile of competition soccer. Can J Sport Sci 1991, 16: 110-116.

11) 大橋二郎, 兵頭圭介, 長浜尚史・他 : サッカー選手の試合中 における移動スピードとAnaerobic Threshold. 体力科学, 1988, 37(6): 656 .

12) Bangsbo J: ATP production and efficiency of human skeletal muscle during intense exercise. Effect of previous exercise. Am J Physiol Endocrinol Metb, 2001, 280: 956-964.

13) 日本サッカー協会 : フィジカル測定ガイドライン 2004 .

14) 坂井和明, 伊藤竜兵, 大高敏弘・他 : 球技スポーツ競技者に おける個別性の原則を考慮した体力トレーニングの効果. 体 育学研究, 2006, 51:21-32.

15) 坂井和明, 水上一, 斎藤一人・他：球技選手における間欠的 なハイパワー発揮能力のトレーニング課題に関する研究. 体 育学研究, 2000, 45: 239-251.

16) 宮城 修: サッカー選手の体力. バイオメカニクス研究, 2006, 10(2): 132-137.

17) Bangsbo J: The Physiology of Soccer-with Specisl Reference to Intermittent Exercise. HO+Storm Copenhagen, 1993, pp111-123.

18）星川佳広, 菅野 淳, 涉川賢一: サッカーにおける体力の研 究. フットボールの科学, 2006, 1(1): 10-17. 